\title{
Trend Analyses of Parameters of Equations for Range CBR Distance Achievable in Ubicomp MANETs Using Location- Aware Transmission.
}

\author{
M. Kaleem GALAMALI, Assoc. Prof Nawaz MOHAMUDALLY
}

\begin{abstract}
The use of MANET transmission methods is considered as probable solution to the problem of inadequately equipped MANET environments. Such situations are very probable in the near future. Significant performance of MANET radically rely on correctly designed protocols for transmission [80]. Adjusting such strategies with location-awareness is believed to uplift the energy management standards and explains all endeavour input by many researchers. Some expected near future deliverables include land-based GPS systems, improved location refresh rates and accuracy, development of sophisticated transmission protocols and less expensive hardware with greater performance. Readily available empirically formulated knowledge concerning trends of distance coverages by transmitted packets in a ubicomp environment over varying node densities, is irrefutably conducive towards refining transmission protocols in MANETs. Accordingly, one such relevant study was conducted in a prior paper [29], whereby metric R_CBR_Dist was discussed.
\end{abstract}

In this paper, the next piece of investigation required for metric R_CBR_Dist is put forward as: "What are the trends of variation observable within each parameter of the equation of curves obtained for metric R_CBR_Dist [29] over varying node densities?". The results presented here may be harnessed by programmers and designers for more judiciously develop ubicomp transmission protocols. This work remains a follow-up of previous work [1-44].

Key terms: Ubicomp- Ubiquitous Computing, MAUCMobile and Ubiquitous Computing, MANET- Mobile Adhoc Network, CBR- Constant Bit Rate, R_CBR_Dist Range CBR Distance.

M. Kaleem GALAMALI,

University of Technology Mauritius (student)

Mauritius

Assoc. Prof Nawaz Mohamudally

University of Technology Mauritius,

Mauritius

\section{Introduction}

It is anticipated that not all future network environments would be plentifully equipped with networking and routing devices. This problem may be more severe in underdeveloped regions or emergency sites. Since ubicomp inherits a lot from distributed systems, it will be subject to lots of heterogeneities [1] which may also dripple into MANET transmission protocols. Yet, MANET transmission remain a salutary choice for such substandard topographies. The performance of such protocols may be further dignified by application of location-awareness and distance considerations. Studying distance related characteristics may be done from perspective of metrics. One such metric, R_CBR_Dist was investigated previously [29], whereby the pattern followed was expressed as the normal distribution model of form:

$F(x)=b *(1 /(a * \operatorname{sqrt}(2 * p i))) * \exp \left(-(x-c)^{2} / 2 * a^{2}\right)$

Here, a quite complex equation of the model is observed with 3 parameters: $a, b$ and $c$. the next empirical upgrade required for metric R_CBR_Dist is the model equations for parameters of equation specified above.

The key contributions of this paper is the elaboration of equations involved for the model for metric R_CBR_Dist expounded previously [29], from which table 1 is re-applied here. The empirical methods extended here may be incorporated into software simulators so that designers and researchers are habilitated with better tools for further investigations of the evolution and predictability of distance features in future ubicomp. The rest of this paper is organised as follows: section 2- Parameter Trend Analysis- Metric R_CBR_Dist, section 3- Conclusion and References.

\section{Parameter Trend Analysis - Metric R_CBR_Dist.}

\subsection{General Procedure Adopted.}

A four step procedure has been defined:

i. The tabulated data for each parameter of the equations for the model for R_CBR_Dist is plotted on gnuplot.

ii. Graphical analyses are performed and general observations are noted.

iii. Different equations of fit are attempted gauged against values of least reduced chi-square and most appreciable extendability at node numbers 80, 100 and 120. 
Proc. of the Seventh International Conference On Advances in Computing, Electronics and Electrical Technology - CEET 2017. Copyright (C) Institute of Research Engineers and Doctors. All rights reserved.

ISBN: 978-1-63248-126-9 doi: 10.15224/ 978-1-63248-126-9-18

iv. The parameter values for each R_CBR_Dist parameter of equation is recorded.

\subsection{Trend Analysis $-R \_C B R \_$Dist parameter " $a$ ".}

The curve depicts an oscillation along an axis which is itself increasing at a decreasing rate. This axis depicts a logarithmic tendency.

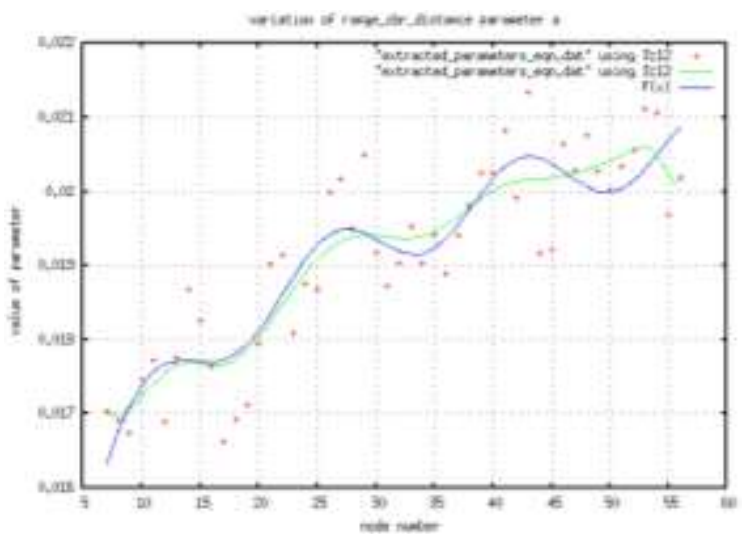

Figure 1: R_CBR_Dist parameter a

The potentially applicable equations are:

1. $F(x)=a * x+b$

$$
\begin{array}{ll}
\text { Ch_sq }=4.83811\left(\mathrm{e}^{-07}\right) & \mathrm{F}(80)=0.022851 \\
\mathrm{~F}(100)=0.024386 & \mathrm{~F}(120)=0.025921
\end{array}
$$

2. $F(x)=a^{*} \sin ((b * x)+c)+d * \log (x)+f$

Ch_sq $=3.89607\left(\mathrm{e}^{-07}\right) \quad \mathrm{F}(80)=0.021172844$

$\mathrm{F}(100)=0.021522 \quad \mathrm{~F}(120)=0.022464$

3. $F(x)=a \star \sin ((b * x)+c)+d * x+f$

$$
\text { Ch_sq }=4.45774\left(\mathrm{e}^{-07}\right) \quad \mathrm{F}(80)=0.022877
$$$$
\mathrm{F}(100)=0.024243 \quad \mathrm{~F}(120)=0.025585
$$

\section{Choice of best fit for R_CBR_Dist parameter a}

The equation in part 2 above has been selected because of both smallest reduced chi-square value obtained and good extendability. The parameters for best fit are:

$\mathrm{a}=0.000411479, \mathrm{~b}=0.391009, \mathrm{c}=3.85595, \mathrm{~d}=$ $0.00213342, \mathrm{f}=0.0120493$

\subsection{Trend Analysis $-R$ CBR Dist parameter " $b$ ".}

Again, the curve depicts an oscillation along an axis which is itself increasing at a decreasing rate. This axis itself depicts logarithmic increase.

The potentially applicable equations are:

$$
\begin{array}{rl}
\text { 1. } F(x)=a * x+b & \\
\text { Ch_sq }=4.0277\left(\mathrm{e}^{-06}\right) & F(80)=0.048633383 \\
F(100)=0.053750 & F(120)=0.058868465 \\
\text { 2. } F(x)=a * \sin ((b * x)+c)+d * x+f \\
\text { Ch_sq }=3.73848\left(e^{-06}\right) & F(80)=0.049051642 \\
F(100)=0.052740 & F(120)=0.058630536 \\
\text { 3. } F(x)=a * \sin ((b * x)+c)+d * \log (x)+f
\end{array}
$$

$$
\begin{array}{ll}
\text { Ch_sq }=3.26411\left(\mathrm{e}^{-06}\right) & \mathrm{F}(80)=0.042828 \\
\mathrm{~F}(100)=0.044268 & \mathrm{~F}(120)=0.047376
\end{array}
$$

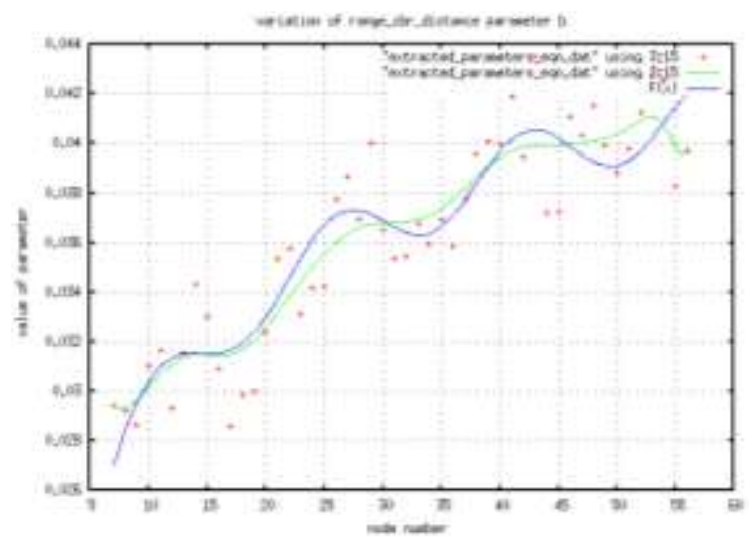

Figure 2: R_CBR_Dist parameter b

Choice of best fit for R_CBR_Dist parameter b

The equation in part 3 above has been selected because of both smallest reduced chi-square value obtained and good extendability. The parameters for best fit are:

$\mathrm{a}=0.00129773, \mathrm{~b}=0.392565, \mathrm{c}=3.87015, \mathrm{~d}=$ $0.00701745, \mathrm{f}=0.0129318$

\subsection{Trend Analysis $-R$ CBR_Dist parameter “c”.}

The curve depicts an increasing tendency at a decreasing rate. This is typical of logarithmic trends.

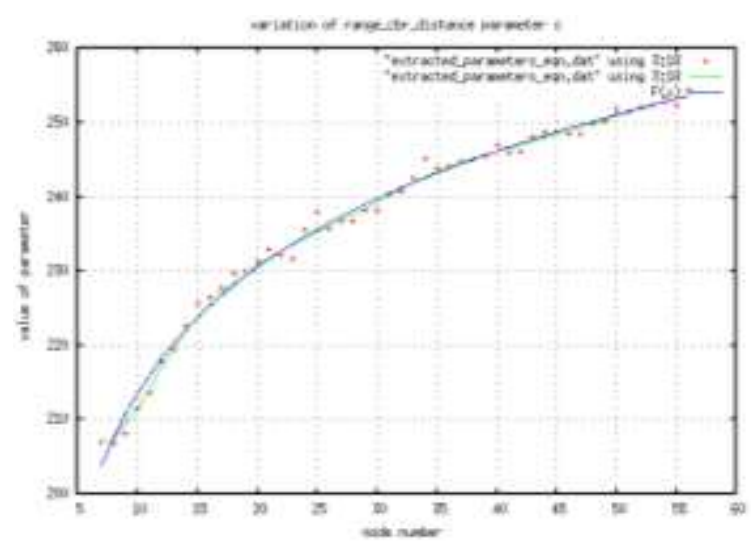

Figure 3: R_CBR_Dist parameter c

The potentially applicable equations are:
1. $F(x)=a * \log ((b * x)+c)+d$ $\begin{array}{ll}\text { Ch_sq }=1.59933 & \mathrm{~F}(80)=261.254717 \\ \mathrm{~F}(100)=266.043710 & \mathrm{~F}(120)=269.940507\end{array}$
2. $F(x)=a * x \star \log ((b * x)+c)+d$ Ch_sq $=18.1395 \quad \mathrm{~F}(80)=280.203188$
$\mathrm{F}(100)=298.188192 \quad \mathrm{~F}(120)=316.300747$
3. $F(x)=a * x^{0.5} * \log ((b * x)+c)+d$
Ch_sq $=7.72832$
$\mathrm{F}(80)=270.883275$
$\mathrm{F}(100)=281.185803 \quad \mathrm{~F}(120)=290.564033$
4. $F(x)=a * x^{-0.5} \star \log ((b * x)+c)+d$ 


$$
\begin{aligned}
& \text { Ch_sq }=3.15121 \\
& \mathrm{~F}(80)=256.361468 \\
& \mathrm{~F}(100)=259.025053 \quad \mathrm{~F}(120)=261.006985 \\
& \text { 5. } F(x)=a^{\star} x^{-1} \star \log ((b * x)+c)+d \\
& \text { Ch_sq }=11.7834 \\
& \mathrm{~F}(80)=251.194431 \\
& \mathrm{~F}(100)=252.358918 \\
& F(120)=253.141250
\end{aligned}
$$

\section{Choice of best fit for R_CBR_Dist parameter c}

The equation in part 1 above has been selected because of both smallest reduced chi-square value obtained and good extendability. The parameters for best fit are:

$a=20.9906, b=49.6301, c=-97.1915, d=87.8339$ computing, CEET 2014

M. Kaleem GALAMALI, Assoc. Prof Nawaz MOHAMUDALLY, Modelling of need for multiple relays for ensuring seamless mobility, CEET 2014

[7] M. Kaleem GALAMALI, Assoc. Prof Nawaz MOHAMUDALLY, Investigation of prominence of placements of relays in a ubicomp topography,

[8] M. Kaleem GALAMALI, Assoc. Prof Nawaz MOHAMUDALLY, Model of energy savings achievable with location-aware transmission in ubicomp using optimised number of relays.

\section{Conclusion.}

This work of advancement of empirical analysis was devised to and has yielded applicable models of trends of the parameters of equations for the metric R_CBR_Dist in a MANET topography of 300 x 300 $\mathrm{m}^{2}$. The models extrapolated here, comprise of mathematical equations of varying complexity. Such mathematical information may give rise to development of processing algorithms for simulator packages for the objective of advanced studies of MANETs. These empirical information will give rise to the pursuit of refined simulator packages for advanced studies of MANETs. The empirical investigation was conducted in gnuplot and criteria of selection of best fit have remained least reduced chi-square and best extendability produced at higher node numbers.

The tenable assumptions made in previous paper [29] are implied here also. The efficacy and accuracy characteristics of gnuplot is reckoned as commensurate for the purpose of this probing.

capability and accuracy level of gnuplot is deemed as adequate for the purpose of this investigation.

Additional work identified here remain: formulating a convenient method of predictability for metric R_CBR_Dist and its trend and reporting specific observations of certain critical values designated.

\section{References}

[1] M. Kaleem GALAMALI, Assoc. Prof Nawaz MOHAMUDALLY, Towards Dependable Pervasive Systems-A Position and Vision Paper, CEET 2014

[2] M. Kaleem GALAMALI, Assoc. Prof Nawaz MOHAMUDALLY, Model of Energy Savings achievable with Location-aware Node-to-Node Transmission in UbiComp , CEET 2014

[3] M. Kaleem GALAMALI, Assoc. Prof Nawaz MOHAMUDALLY, Model of Energy Savings achievable with Location-aware Node-to-Node Transmission in
[9] M. Kaleem GALAMALI, Assoc. Prof Nawaz MOHAMUDALLY, Investigation of Prominence of Placements of Optimised Number of Relays in a Ubicomp Topography using Location-Aware Transmission, CEET 2015.

[10] M. Kaleem GALAMALI, Assoc. Prof Nawaz MOHAMUDALLY, Extending Node Battery Availability in Ubicomp with Location-Aware Transmission, CEET 2015.

[11] M. Kaleem GALAMALI, Assoc. Prof Nawaz MOHAMUDALLY, Extending Node Battery Availability in Ubicomp with Location-Aware Transmission using Location

[12] M. Kaleem GALAMALI, Assoc. Prof Nawaz MOHAMUDALLY, Extending Node Battery Availability in Ubicomp with Location-Aware Transmission using Uniformly Placed Relays, CEET 2015.

[13] M. Kaleem GALAMALI, Assoc. Prof Nawaz MOHAMUDALLY, Extending Node Battery Availability in Ubicomp with Location-Aware Transmission Using Optimally Placed Relays, CEET 2015.

[14] M. Kaleem GALAMALI, Assoc. Prof Nawaz MOHAMUDALLY, Model of Sender Node Energy Savings Achievable with Location-Aware MANET Transmission in Ubicomp. ACCN 2016

[15] M. Kaleem GALAMALI, Assoc. Prof Nawaz MOHAMUDALLY, Model of Overall Node Energy Savings Achievable with Location-Aware MANET Transmission in Ubicomp. ACCN 2016

[16] M. Kaleem GALAMALI, Assoc. Prof Nawaz MOHAMUDALLY, Model of Sender Node Extra Energy Savings Achievable in MANET Against Direct Node-toNode Transmission Using Location-Aware Transmission in Ubicomp. ACCN 2016

[17] M. Kaleem GALAMALI, Assoc. Prof Nawaz MOHAMUDALLY, Model of Overall Node Extra Energy Savings Achievable in MANET against Direct Node-toNode Transmission Using Location-Aware Transmission in Ubicomp. ACCN 2016

[18] M. Kaleem GALAMALI, Assoc. Prof Nawaz MOHAMUDALLY, Model of Energy Consumption Ratio Achievable in MANET Using Location-Aware Transmission in Ubicomp. ACCN 2016

[19] M. Kaleem GALAMALI, Assoc. Prof Nawaz MOHAMUDALLY, Model of Minimum Energy Consumption Ratio Achievable in MANET Using LocationAware Transmission in Ubicomp. ACCN 2016

[20] M. Kaleem GALAMALI, Assoc. Prof Nawaz MOHAMUDALLY, Model of Maximum Energy Consumption Ratio Achievable in MANET Using LocationAware Transmission in Ubicomp. ACCN 2016

[21] M. Kaleem GALAMALI, Assoc. Prof Nawaz MOHAMUDALLY, Model of Overall Energy Consumption Fairness Ratio Achievable in MANET Using LocationAware Transmission in Ubicomp. ACCN 2016

[22] M. Kaleem GALAMALI, Assoc. Prof Nawaz MOHAMUDALLY, Model of Overall Energy Consumption Aware Transmission for Ubicomp, CEET 2016 Refresh Intervals, CEET 2015. Fairness Proportion Achievable in MANET Using Location- 
[23] M. Kaleem GALAMALI, Assoc. Prof Nawaz MOHAMUDALLY, Model of Minimum Fairness Proportion Achievable in MANET Using Location-Aware Transmission for Ubicomp, CEET 2016

[24] M. Kaleem GALAMALI, Assoc. Prof Nawaz MOHAMUDALLY, Model of Maximum Fairness Proportion Achievable in MANET Using Location-Aware Transmission for Ubicomp, CEET 2016

[25] M. Kaleem GALAMALI, Assoc. Prof Nawaz MOHAMUDALLY, Model of Sender Fairness Proportion Achievable in MANET Using Location-Aware Transmission for Ubicomp, CEET 2016

[26] M. Kaleem GALAMALI, Assoc. Prof Nawaz MOHAMUDALLY, Model of Distance Travelled by packets in MANETs using Location-Aware Transmission for Ubicomp, CEET 2016

[27] M. Kaleem GALAMALI, Assoc. Prof Nawaz MOHAMUDALLY, Model of Maximum CBR Distance Travelled by packets in MANETs using Location-Aware Transmission for Ubicomp, CEET 2016

[28] M. Kaleem GALAMALI, Assoc. Prof Nawaz MOHAMUDALLY, Model of Minimum CBR Distance Travelled by packets in MANETs using Location-Aware Transmission for Ubicomp, CEET 2016

[29] M. Kaleem GALAMALI, Assoc. Prof Nawaz MOHAMUDALLY, Model of Range CBR Distance Experienced by Transmissions in MANETs using LocationAware Transmission for Ubicomp, CEET 2016

[30] M. Kaleem GALAMALI, Assoc. Prof Nawaz MOHAMUDALLY, Trend Analyses of Parameters of Equations for Sender Node Energy Savings Achievable in ubicomp MANETs using Location-Aware Transmission, ACCN 2017.

[31] M. Kaleem GALAMALI, Assoc. Prof Nawaz MOHAMUDALLY, Trend Analyses of Parameters of Equations for Overall Node Energy Savings Achievable in ubicomp MANETs using Location-Aware Transmission, ACCN 2017.

[32] M. Kaleem GALAMALI, Assoc. Prof Nawaz MOHAMUDALLY, Trend Analyses of Parameters of Equations for Sender Node Extra Energy Savings Achievable in MANET against Direct Node-to-Node Location-Aware Transmission, ACCN 2017.

[33] M. Kaleem GALAMALI, Assoc. Prof Nawaz MOHAMUDALLY, Trend Analyses of Parameters of Equations for Overall Nodes Extra Energy Savings Achievable in MANET against Direct Node-to-Node Location-Aware Transmission, ACCN 2017.

[34] M. Kaleem GALAMALI, Assoc. Prof Nawaz MOHAMUDALLY, Trend Analyses of Parameters of Equations for Energy Consumption Ratio Achievable in Ubicomp MANET Using Location-Aware Transmission, ACCN 2017.

[35] M. Kaleem GALAMALI, Assoc. Prof Nawaz MOHAMUDALLY, Trend Analyses of Parameters of Equations for Minimum Energy Consumption Ratio Achievable in Ubicomp MANETs Using Location-Aware Transmission, ACCN 2017.

[36] M. Kaleem GALAMALI, Assoc. Prof Nawaz MOHAMUDALLY, Trend Analyses of Parameters of Equations for Maximum Energy Consumption Ratio Achievable in Ubicomp MANETs Using Location-Aware Transmission, ACCN 2017

[37] M. Kaleem GALAMALI, Assoc. Prof Nawaz MOHAMUDALLY, Trend Analyses of Parameters of Equations for Overall Fairness Ratio Achievable in Ubicomp MANETs Using Location-Aware Transmission, ACCN 2017.

[38] M. Kaleem GALAMALI, Assoc. Prof Nawaz MOHAMUDALLY, Trend Analyses of Parameters of Equations for Energy Consumption Fairness Proportion Achievable in Ubicomp MANETs Using Location-Aware Transmission, CEET 2017

[39] M. Kaleem GALAMALI, Assoc. Prof Nawaz MOHAMUDALLY, Trend Analyses of Parameters of Equations for Minimum Fairness Proportion Achievable in Ubicomp MANETs Using Location-Aware Transmission, CEET 2017

[40] M. Kaleem GALAMALI, Assoc. Prof Nawaz
MOHAMUDALLY, Trend Analyses of Parameters of Equations for Maximum Fairness Proportion Achievable in Ubicomp MANETs Using Location-Aware Transmission, CEET 2017

[41] M. Kaleem GALAMALI, Assoc. Prof Nawaz MOHAMUDALLY, Trend Analyses of Parameters of Equations for Sender Fairness Proportion Achievable in Ubicomp MANETs Using Location-Aware Transmission, CEET 2017

[42] M. Kaleem GALAMALI, Assoc. Prof Nawaz MOHAMUDALLY, Trend Analyses of Parameters of Equations for Packets Per Distance Achievable in Ubicomp MANETs Using Location-Aware Transmission, CEET 2017

[43] M. Kaleem GALAMALI, Assoc. Prof Nawaz MOHAMUDALLY, Trend Analyses of Parameters of Equations for Maximum CBR Distance Achievable in Ubicomp MANETs Using Location-Aware Transmission, CEET 2017

[44] M. Kaleem GALAMALI, Assoc. Prof Nawaz MOHAMUDALLY, Trend Analyses of Parameters of Equations for Minimum CBR Distance Achievable in Ubicomp MANETs Using Location-Aware Transmission, CEET 2017

[45] Markus Bylund and Zary Segall, Towards seamless mobility with personal servers, 2004.

[46] Masugi Inoue, Mikio Hasegawa, Nobuo Ryoki and Hiroyuki Morikawa, Context-Based Seamless Network and Application Control, 2004

[47] Xiang Song, Umakishore Ramachandran, MobiGo: A Middleware for Seamless Mobility, College of Computing Georgia Institute of Technology, Atlanta, GA, USA, August 2007

[48] Budzisz, Ferrús, R., Brunstrom A., Grinnemo, K, Fracchia, R., Galante, G., and Casadevall, F. Towards transport-layer mobility: Evolution of SCTP multihoming, March 2008

[49] Paul Dourish \& Genevieve Bell, Divining a digital future, 2011

[50] Xiang Song, Seamless Mobility In Ubiquitous Computing Environments, PhD Thesis, Georgia Institute of Technology, August 2008

[51] Kevin O Mahony, Jian Liang, Kieran Delaney, User-Centric Personalization and Autonomous Reconfiguration Across Ubiquitous Computing Environments, NIMBUS Centre Cork Institute of Technology, Cork, Ireland, UBICOMM 2012

[52] Pablo Vidales, Seamless mobility in $4 \mathrm{G}$ systems, Technical Report, University of Cambridge, Computer Laboratory, Number 656, November 2005

[53] João Pedro Sousa and David Garlan, Aura: An Architectural Framework for User Mobility in Ubiquitous Computing Environments, School of Computer Science, Carnegie Mellon University, USA, August 2002

[54] Dennis Lupiana, Ciaran O'Driscoll, Fredrick Mtenzi, Defining Smart Space in the Context of Ubiquitous Computing, Dublin Institute of Technology, Ireland, Special Issue on ICIT 2009 Conference - Web and Agent Systems, 2009

[55] N.S.V.Shet1, Prof.K.Chandrasekaran2 and Prof. K.C.Shet3, WAP Based Seamless Roaming In Urban Environment with Wise Handoff Technique, International Journal of UbiComp (IJU), Vol.1, No.4, October 2010

[56] Yipeng Yu Dan He Weidong Hua Shijian Li Yu Q Yueming Wang Gang Pan, FlyingBuddy2: A Braincontrolled Assistant for the Handicapped, Zhejiang University, UbiComp'12, September 5-8, 2012.

[57] Jing Su, James Scott, Pan Hui, Jon Crowcroft, Eyal de Lara Christophe Diot, Ashvin Goel, Meng How Lim, and Eben Upton, Haggle: Seamless Networking for Mobile Applications, 2007

[58] Rui Han, Moustafa M. Ghanem, Li Guo, Yike Guo*, Michelle Osmond, Enabling cost-aware and adaptive elasticity of multi-tier cloud applications, Future Generation Computer Systems, 2012

[59] Byrav Ramamurthy, K. K. Ramakrishnan, Rakesh K. Sinha, Cost and Reliability Considerations in Designing the NextGeneration IP over WDM Backbone Networks, 2012.

[60] Bhavish Aggarwal, Aditya Akella, Ashok Anand, Athula Balachandran, Pushkar Chitnis, Chitra Muthukrishnan, Ram Ramjee and George Varghese, EndRE: An End-System 
Redundancy Elimination Service for Enterprises, NSDI 2010, San Jose, CA

[61] Ashok Anand, Vyas Sekar and Aditya Akella, SmartRE: An Architecture for Coordinated Network-wide Redundancy Elimination, SIGCOMM 2009, Barcelona, Spain

[62] John Breeden II, "Smart-phone battery life could double without better batteries", Nov 14, 2012

[63] Andy Boxall, "When will your phone battery last as long as your kindle", December 5, 2012.

[64] Imielinski, T. and Navas, J.C. (1999). GPS-based geographic addressing, routing, and resource discovery. Comms. ACM, Vol. 42, No. 4, pp. 86-92.

[65] Hightower, J. and Borriello, G. (2001). Location Systems for Ubiquitous Computing. IEEE Computer, Vol. 34, No. 8, August, pp. 57-66.

[66] Harter, A., Hopper, A., Steggles, P., Ward, A. and Webster, P. (2002). The Anatomy of a Context-Aware Application. Wireless Networks, Vol. 8, No. 2-3, Mar-May, pp. 187-197.

[67] Hightower, J., Brumitt, B. and Borriello, G. (2002). The Location Stack: A Layered Model for Location in Ubiquitous Computing. Proceedings of the 4th IEEE Workshop on Mobile Computing Systems \& Applications (WMCSA 2002), Callicoon, NY, USA, June, pp. 22-28.

[68] Graumann, D., Lara, W., Hightower, J. and Borriello, G. (2003). Real-world implementation of the Location Stack: The Universal Location Framework. Proceedings of the 5th IEEE Workshop on Mobile Computing Systems \& Applications (WMCSA 2003), Monterey, CA, USA, October, pp. 122-128.

[69] Ko, Y., \& Vaidya, N. H. (2000). Location-aided routing (LAR) in mobile ad hoc networks. Wireless Networks, 6(4), 307-321.

[70] Liao, W.-H., Tseng, Y.-C., \& Sheu, J.-P. (2001). GRID: a fully location-aware routing protocol for mobile ad hoc networks. Telecommunication Systems, 18(1), 37-60.

[71] Kuhn, F., Wattenhofer, R., Zhang, Y., \& Zollinger, A. (2003). Geometric ad-hoc routing: of theory and practice. In Proceedings of the ACM (PODC'03) (pp. 63-72).

[72] Jiang, X., \& Camp, T. (2002). Review of geocasting protocols for a mobile ad hoc network. In Proceedings of the Grace Hopper Celebration (GHC).

[73] Ko, Y. \& Vaidya, N. H. (1999). Geocasting in mobile ad hoc networks: location-based multicast algorithms. In Proceedings of the IEEE (WMCSA'99) (pp. 101).

[74] Mauve, M., Fuler, H., Widmer, J., \& Lang, T. (2003). Position-based multicast routing for mobile ad-hoc networks (Technical Report TR-03-004). Department of Computer Science, University of Mannheim.

[75] Xu, Y., Heidemann, J., \& Estrin, D. (2001). Geographyinformed energy conservation for adhoc routing. In Proceedings of the ACM/IEEE (MOBICOM'01) (pp. 70-84).

[76] Hu, Y.-C., Perrig, A., \& Johnson, D. (2003). Packet leashes: a defense against wormhole attacks in wireless ad hoc networks. In Proceedings of the INFOCOM' 03 (pp. 19761986).

[77] Patwari, N., Hero III, A. O., Perkins, M., Correal, N. S., \& O'Dea, R. J. (2003). Relative location estimation in wireless sensor networks. IEEE Transactions on Signal Processing, 51(8), 2137-2148.

[78] Baldauf, M., Dustdar, S., \& Rosenberg, F. (2007). A Survey on Context Aware Systems. International Journal of Ad Hoc and Ubiquitous Computing, Inderscience Publishers. forthcoming. Pre-print from: http://www.vitalab.tuwien.ac.at/ florian/papers/ijahuc2007.pdf

[79] Hong, D., Chiu, D.K.W., \& Shen, V.Y. (2005). Requirements elicitation for the design of context-aware applications in a ubiquitous environment. In Proceedings of ICEC'05 (pp. 590-596).

[80] Neeraj Tantubay, Dinesh Ratan Gautam and Mukesh Kumar
Dhariwal, A Review of Power Conservation in Wireless Mobile Ad hoc Network (MANET)", International Journal of computer Science Issues, Vol 8, Issue 4, No 1, July 2011.

[81] Wenrui Zhao, Mostafa Ammar and Ellen Zegura, "A Message Ferrying Approach for Data Delivery in Sparse Mobile Ad Hoc Networks", MobiHoc'04, May 24-26, 2004, Roppongi, Japan.

About Author (s):

Associate Professor Nawaz Mohamudally works at University of Technology, Mauritius (UTM) and has undertaken supervision of MPhil/PhD Students for many years.

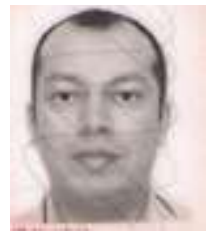

M. Kaleem Galamali is a part-time student (achieved M Phil Transfer on 28.10.2014, currently $\mathrm{PhD}$ student) at UTM under supervision of A.P. Nawaz Mohamudally. 